\title{
Determinants of Entrepreneurship Intention Based on Individual Aspects
}

Siti Asiyah ${ }^{1}$

1Manajemen, Universitas Islam Malang, Indonesia

\begin{tabular}{|c|c|}
\hline ARTICLE INFO & ABSTRACT \\
\hline $\begin{array}{l}\text { Keywords: Attitude to } \\
\text { Behavior, Entrepreneurship } \\
\text { Education, Entrepreneurial } \\
\text { Intention,Self-Efficacy, } \\
\text { Subjective Norms. }\end{array}$ & $\begin{array}{l}\text { This investigation expects to decide the impact of (1) self- } \\
\text { viability; (2) emotional standards; ( } 3 \text { ) demeanor toward conduct; } \\
\text { and (4) enterprise instruction towards understudy business } \\
\text { goals. This research comprised of } 278 \text { understudies as } \\
\text { respondents. The instrument legitimacy test utilizes } \\
\text { Confirmatory Factor Analysis, while the unwavering quality test } \\
\text { utilizes Cronbach Alpha. The investigation system utilized is } \\
\text { different direct relapse test. The consequences of the examination } \\
\text { found that. (1) self-adequacy positively affects innovative } \\
\text { expectations, (2) emotional standards positively affect } \\
\text { pioneering aims, (3) conduct positively affects enterprising goals, } \\
\text { (4) business enterprise instruction positively affects enterprising } \\
\text { aims. }\end{array}$ \\
\hline
\end{tabular}

\section{Introduction}

Right now Indonesia is as yet encountering joblessness issues. The quantity of work power isn't corresponding to the quantity of employments accessible. Network direction is as of now centered around the formal part, with the goal that when the formal segment is languid, the network does make an effort not to make their own occupations in the non-formal area or the private segment[1]. This is the motivation behind why the quantity of jobless individuals in Indonesia is still very high[2].

One approach to defeat joblessness and improve the Indonesian economy is to expand the enthusiasm of youngsters in enterprise. A nation can succeed if in any event $2 \%$ of the populace progresses toward becoming business people. For Indonesia, $2 \%$ of the 250 million populace implies 5 million business visionaries, this number is a long way from the real world, in light of the fact that the quantity of Indonesian business visionaries is just around 450,000 business visionaries, or just $0.18 \%$ of the number of inhabitants in Indonesia[3]. The improvement of business visionaries or pioneering exercises is generally excellent in created nations[4]. For instance in the United States the enterprise rate is $11.5-12 \%$, Singapore has $7 \%$ business enterprise, China and Japan at $10 \%$ of the nation's populace[5].

Indonesia needs around 4.6 million business people, while the number accessible under the formal business approach is just 564,240 business visionaries or there are still around 4.07 million new business visionaries. In Indonesia, joblessness is right now ruled by instructed jobless or those with single guy, institute and secondary school training[6]. The modest number of business visionaries is identified with the low enterprising goals. The expectation of business enterprise is the capacity to be bold in 
gathering life's needs and tackling life's issues. The expectation of enterprise is the inclination of people to make pioneering move by making new items through business openings and hazard taking. The goal of enterprise is estimated by the size of pioneering expectation with markers picking the way of business instead of working for other people, picking a vocation as a business visionary, making arrangements to begin a business, improving economic wellbeing (confidence) as a business visionary and winning more pay well[7].

In view of the pre overview results, the specialist will execute Theory of Planned Behavior (TPB) which is a further advancement of Theory of Reasoned Action (TRA). The contrast between Theory of Planned Behavior (TPB) and Theory of Reasoned Action (TRA) is an extra determinant of conduct goal that is seen social control (PBC). PBC is controlled by the factor of Control conviction (trust in the capacity to control). This build was included a push to comprehend the restrictions controlled by people so as to play out specific practices[8].

In view of the Theory of Planned Behavior (TPB), that a conduct with high inclusion requires certainty and assessment to encourage mentalities, emotional standards, and social control with expectations as middle people of the impact of different inspirational variables that effect on a conduct[9]. Enterprising choices are practices with high contribution (high inclusion) on the grounds that in settling on choices will include elements Believing in one's own capacities (self-adequacy), being sure (mentality towards conduct), and ecological help (abstract standards). At the end of the day, the expectation or conduct of an activity or not will be dictated by emotional frames of mind and standards, yet in addition the person's impression of the control he can do that originates from his convictions on those controls (control convictions). In the interim, conduct control is operationalized with self-viability. So the focal point of the Theory of Planned Behavior is on one's goal to play out a conduct, since goal is the premise of a conduct[3].

Another factor that can impact innovative expectations is the logical factor in enterprise instruction where business enterprise training is relied upon to encourage the longing and goal of. In light of past research, the outcomes demonstrated that the variable frame of mind, abstract standards, and self-viability positively affect understudy business enterprise goals[4]. The demeanor, social standards, emotional standards, and self-viability effectsly affected understudies at 6 colleges in Indonesia. Relevant factors, for example, enterprise training positively affected innovative expectations of understudies in the workforce of financial aspects and organization, Yasar University, Izmir, Turkey. From the above research is as yet restricted to inner elements or simply inspect TPB just, the creators include logical factors specifically business enterprise training as a supplement in this examination. Subsequently, the creators take the title of the exploration the effect of self-efficacy, objective norms, behavior attitudes, and entrepreneurship education toward entrepreneurial intentions[7].

\section{Research Methods}

The author uses quantitative research. Information obtained through surveys by distributing questionnaires. The scale used is the Likert scale where the respondent 
stated the level of agreement or disagreement regarding various statements regarding behavior, objects, people or events. The proposed scale consists of 4 choices, namely Strongly Agree (SS), Agree (S), Disagree (TS) and Strongly Disagree (STS). This research was conducted by taking location at the Faculty of Economics, in East Java. This study used the Krejcie and Morgan method using the chi-quadrat approach, $\mathrm{p}=0.5$, with an error limit assumed to be $5 \%(0.05)$. In this study the variables are determined based on the theoretical basis of attitudes, subjective norms, self-efficacy, entrepreneurship education, and entrepreneurial intentions.

Data analysis: in view of the aftereffects of the examination note that the estimation of the Kaiser-Meyer-Olkin Measure of Sampling Adequacy (KMO MSA) is more noteworthy than 0.50 which is equivalent to 0.883 , this demonstrates the current information is attainable for investigation, while the consequences of the Bartlett's Test of Sphericity are gotten the essentialness level is 0,000, which implies that between factors there is a relationship (criticalness $<0.05$ ), along these lines it tends to be reasoned that every current variable can be additionally broke down in light of the fact that they meet the criteria. The dependability test outcomes demonstrated that all inquiry things of the three factors concentrated were solid since they had a Cronbach Alpha value $>0.70$. Hence, the appropriate responses from respondents as per reality and the following stage can be played out different relapse investigation.

\section{Result and Discussion}

Theoretical framework and hypotheses: Intention of Entrepreneurship: Goal is the genuineness of one's expectation to complete a demonstration or achieve a specific conduct. In enterprise exercises must be founded on the aim that business exercises can run reliably. That is, each person when choosing business enterprise must have the goal as a main thrust in business enterprise. The accompanying comprehension of enterprising aims as indicated by certain specialists. Goal is the earnestness of one's aim to play out an activity or raise a certain behavior [8]. The aim of enterprise is the capacity to have the mental fortitude to address the issues of life and take care of life issues, advance business or make new organizations with existing quality in oneself. In the interim. The goal of en- trepreneurship is characterized as the way toward discovering data that can be utilized to accomplish the targets of shaping a business [6].

Expectation of business is a mental wonder to center consideration and take care of the businessperson with a sentiment of joy since it carries advantages to himself. As a rule, ex-pectation precursor variables can be communicated through Theory Planned of Behavior (TPB), to be specific convictions or frames of mind to carry on, abstract standards and control of conduct or self-adequacy. The arrangement of expectations can be clarified by arranged conduct hypothesis which accept people always have objectives in conduct[4]. Other than that, expectation additionally indicates how hard somebody is attempting, goal demonstrates how much exertion some-body is intending to do and aim is most firmly identified with ensuing conduct [1].

Theory of planned behavior: hypothesis of Planned Behavior is a hypothesis with respect to explicit conduct in people. Theory of Planned Behavior is a Theory of Reasoned Action that is upgraded by the expansion of Perceived Behavior Control or in operationally called self-adequacy [3]. The fundamental worry in the hypothesis of 
arranged conduct is the expectation or aim of an individual to play out a conduct. Since expectation is a transitional variable that causes the conduct of a demeanor or different factors. Expectation is an arbiter of the impact of different persuasive components that affect a conduct. Moreover, the aim additionally demonstrates how hard somebody sets out to attempt [7]. Goal indicates how much exertion an individual intends to do, and goal is most firmly identified with ensuing conduct.

Subjective Norms: abstract standards are singular convictions about the encompassing condition and individual inspiration to pursue these standards. The fundamental part of abstract standards, in particular confidence in expectation, is the perspective on different gatherings that are viewed as significant by people who encourage people to or must not carry on [8]. So abstract standards can impact innovative goals from the outer side as help for the earth, both family and grounds condition. Somebody will get excitement if they get support from individuals around them. Abstract standards are view of social weight in completing certain practices. Abstract standards are singular convictions to comply with the mandates or proposals of people around them to take part in enterprising exercises [7].

Attitude: The frame of mind is the premise of the aims where mentalities have parts of the subject that is the conviction of people that showing or not showing the conduct of certain will deliver an outcome or result certain, the more constructive contemplations an individual then it will be progressively construc-tive also the demeanor of people towards the article [9]. Frame of mind characterized inclinations are concentrated to give a reaction to the article or class of items are reliably great in taste loves or dislikes. Frame of mind is a fondness or feeling towards an improvement [5]. In certain examinations the innovative demeanor of business enterprise operationalized in re-sistance of hazard and set out to confront snags. So mentalities can impact goals somebody to business of the choices he's going out on a limb or maintain a strategic distance from it[8].

Business Education: advanced education can be viewed as a potential wellspring of printing for planned business peo-ple. At the point when this, most significant colleges have contributed very huge for planning instruc-tive business enterprise that is possible for understudies [9]. As per the understanding that increasingly broad, instruction business visionary ship is characterized as the whole scope of exercises of training and preparing in the arrangement of instruction or not, which is attempting to create goal on members to play out the conduct of enterprise, or a portion of the components that influence expectations, for example, information, business enterprise, ability action pioneering, or their qualification [1].

One of the components driving the development of business enterprise in an arranged a shot the job of colleges high through instruction business enterprise. In the examination pastly presumed that, while the college gives information and motivation that is sufficient for business, the likelihood to expand the craving of business visionary ship in among youngsters more youthful [3]. Gathering school high has obligation duty to teach and set up the businesspeople more youthful who are relied upon to energize the development of the economy in a nation. Gathering school high is relied upon to have the option to apply the example of discovering that is suitable and solid that depends on input exact which is required to encourage the soul of understudies to 
business. The issue that emerges is the way to develop enterprising inspiration after understudies become graduates [4].

In view of a few investigations that have been directed, reasoned that the expectation of business vi- sionary ship affected by a few elements, for example, variables of inward, outer, and relevant that it incorporates instructive enterprise. The job of business education is significant during the time spent shaping business visionaries. In principle accepted that on the off chance that the instruction of business enterprise given since right on time, at that point it will expand the potential for somebody become an entrepreneur [5].

Effect of self- efficacy on entrepreneurial intentions: self-viability is required for a business visionary. Self-viability is one's faith in his capacity to finish a vocation. Or on the other hand as it were, an individual's inspirational conditions depend more on what they trust in than what is dispassionately valid [3]. Self-adequacy has a significant job towards innovative aims, with a solid self-viability, an individual will be progressively certain about what he is doing and there is no uncertainty when making a move for enterprise. Aim or a compelling impulse from inside yourself is required for the arrangement to manufacture a business. Without the aim as a rule people will be hesitant to begin a business [2].

Goal is the genuineness of one's expectation to play out an activity or raise a specific conduct. Thus, it very well may be presumed that self-viability fortifies one's expectation and (goal) to make a move, in this unique situation, innovative exercises [8]. This is strengthened by research: With self-viability, the drive or expectation for business enterprise will be more grounded. In this way, the theory can be finished up as pursues:

H1: Self-efficacy Influences Entrepreneurial Intention: Effect of Subjective Norm Against the intention of Entrepreneurship: A businessperson has emotional standards to be increasingly certain and eager about beginning a business. Abstract standards are the person's convictions to comply with the bearing or exhortation of everyone around him. While as indicated by specialists' emotional standards are items and view of social weight in completing certain practices [2]. Emotional standards have a significant job in expanding pioneering expectations because abstract standards are a type of help from the encompassing condition in this setting is support for business [4]. This help can emerge out of family, companions, instructors, specialists, and individuals who are viewed as significant. It very well may be inferred that when an individual gets solid help from the earth or family, there will be a goal and trust in that individual [5]. Abstract standards have a solid impact in encouraging innovative goals. In this manner, the speculation can be finished up as pursues:

H2: Subjective Norms Influence Entrepreneurial Intention: Influence Attitudes behave Against the intention of Entrepreneurship: Though as per specialist's emotional standards are items and impression of social weight in completing certain practices. This help can emerge out of family, companions, instructors, businessmen, and individuals who are viewed as significant. It tends to be presumed that when an individual gets solid help from the earth or family, there will be a goal and trust in that individual [3]. Abstract standards have a significant job in expanding innovative expectations because emotional standards are a type of help from the encompassing condition in this setting is support for business enterprise [4]. A businessperson has abstract standards to be increasingly 
certain and excited about beginning a business. Emotional standards are the person's convictions to comply with the heading or guidance of people around him [6]. Abstract standards have a solid impact in cultivating enterprising expectations. In this way, the speculation can be closed as pursues:

H3: Attitudes Behavior Influential Against the intention of Entrepreneurship: Effect of Educational Entrepreneurship Against the intention of Entrepreneurship Enterprise training is significant in pioneering exercises. business enterprise instruction is characterized in general arrangement of instructive and preparing exercises in the training framework or not, which attempts to build up an expectation for members to take part in innovative conduct, or a few components that impact goals, for example, information, business, want for pioneering exercises, or their qualification [4]. In its advancement, business enterprise training is nearly held by numerous colleges today. In the examination it was reasoned that business enterprise instruction expands understudy pioneering expectations [3]. Therefore, the accompanying speculations can be drawn. H4: Attitude Behavior Influential Against the intention of Entrepreneurship.

Result: Considering data got from the examination results, a few ends can be drawn as pursues. Self-adequacy (X1) positively affects innovative goals (Y). This can be demonstrated through relapse examination it is realized that the impact of self-viability impacts the Intention of entrepreneurhip by $(\beta) 0.256\left({ }^{* *} p<0.05 ; p=0.000\right)$. The greatness of the impact of work inspiration on pioneering goals is $(\Delta R 2) 0.023^{* *}$. In view of these outcomes, it tends to be inferred that there is a beneficial outcome of Self-Efficacy on the Intention of Entrepreneurship. Along these lines, understudies who have an abnormal state of Self-Efficacy or fearlessness will expand their expectation to progress toward becoming business visionaries, since understudies will turn out to be progressively certain about their capacities and will lose their dread when starting a business.

Emotional Norms (X2) positively affect innovative aims (Y) Undergraduate students. This can be demonstrated through relapse examination; it is realized that the impact of Subjective Norms on Entrepreneurial Intention is $(\beta) 0.264{ }^{* *} p<0.05$; $p=$ $0.000)$. The impact of emotional standards on pioneering expectations is $(\Delta R 2) 0.021^{* *}$. In view of this it very well may be presumed that there is a positive impact of Subjective Norms on the Intention of Entrepreneurship, and it tends to be inferred that the subsequent speculation is acknowledged. Along these lines, on the off chance that emotional standards or the help of the encompassing condition is solid, at that point understudies will be increasingly certain to set out to start a business.

The mentality of conduct (X3) affects the goal of business (Y). This can be demonstrated through relapse investigation; it is realized that the impact of disposition toward business expectation is $(\beta) 0.281\left({ }^{* *} p<0.05 ; p=0.000\right)$. The impact of disposition toward the innovative expectation is $(\Delta R 2) 0.022^{* *}$. In view of this, it tends to be reasoned that there is a positive effect on demeanor toward the enterprise expectations and it very well may be presumed that the third speculation is acknowledged. Along these lines, on the off chance that the frame of mind is solid, at that point understudies will be progressively certain to set out to start organizations.

Enterprise training (X4) positively affects pioneering expectations $(\mathrm{Y})$. This can be demonstrated through a relapse investigation that the impact of enterprise training on innovative aims is $(\beta) 0,278\left({ }^{* *} p<0.05 ; p=0,000\right)$. The impact of business enterprise 
training on business enterprise aims is $(\Delta R 2) 0.028^{* *}$. In light of this, it very well may be reasoned that there is a positive effect on business enterprise instruction on the business goals and it tends to be inferred that the fourth speculation is acknowledged. In this way, if business enterprise training can be completed well, it will assist understudies with having an image of business enterprise so the degree of want to play business enterprise on words will increment.

\section{Conclusion}

Based on the results of research, discussion, and conclusions obtained, the suggestions that can be given are as follows. The undergraduate students should better approach the learning in business entrepreneurship with an internal approach that is the main foundation in starting being an entrepreneur. Based on the assessment of respondents in this study, the actual level of internal student foundation such as selfefficacy, attitude toward behavior, subjective norms is still lacking so that only a few students intend to become entrepreneurs. The campus should pay more attention to the formation of an entrepreneurial mentality on each individual, so that when they will be given lessons or direction on entrepreneurial activities the students will be far more interested in the field of entrepreneurship. In addition, entrepreneurship education must be further optimized as a forum for students to find solutions to the problems of the entrepreneurial world they face. The next researcher can develop this research by further investigating the level of action for entrepreneurship, because in this study the focus is more on the level of intention or intention in entrepreneurship. By conducting further research it will be able to develop entrepreneurship in the younger generation.

\section{References}

[1] F. S. Foltean, S. M. Trif, and D. L. Tuleu, “Customer Relationship Management Capabilities and Social Media Technology Use: Consequences on Firm Performance," J. Bus. Res., no. December 2017, pp. 1-13, 2018, doi: 10.1016/j.jbusres.2018.10.047.

[2] M. Bagheri and H. Khorrami, "Evaluating Human Factors in customer Relationship Management (Case Study: Private Banks of Shiraz City)," Procedia Econ. Financ., vol. 36, no. 16, pp. 363-373, 2016, doi: 10.1016/S2212-5671(16)30048$X$.

[3] Santoso, Rudi; Shinta, Rahayu; Fianto, Achmad Yanu Alif. Pengaruh Bauran Pemasaran Jasa Terhadap Keputusan Berkunjung Ke Wisata Bahari Jawa Timur. Jurnal MEBIS (Manajemen dan Bisnis), 2019, 4.2: 73-86.

[4] A. Ghazian, M. Hasan, and H. Farsijani, "The Effect of customer Relationship Management and its Significant Relationship by customers' Reactions in LG Company," Procedia Econ. Financ., vol. 36, no. 16, pp. 42-50, 2016, doi: 10.1016/S2212-5671(16)30014-4.

[5] Y. Li, J. Huang, and T. Song, "Examining Business Value of customer Relationship Management Systems: IT Usage and Two-Stage Model Perspectives," Inf. Manag., vol. 7, no. 12, 2018, doi: 10.1016/j.im.2018.07.012. 
[6] Fianto, Achmad Yanu Alif. Satifaction As Intervening For The Antecedents Of Intention To Revisit: Marine Tourism Context In East Java. Relasi: Jurnal Ekonomi, 2020, 16.1: 179-207.

[7] T. Ritter and J. Geersbro, "Multidexterity in customer Relationship Management: Managerial Implications and a Research Agenda," Ind. Mark. Manag., 2018, doi: 10.1016/j.indmarman.2018.01.019.

[8] M. Yadollahinia, E. Teimoury, and M. Mahdi, "Tire Forward and Reverse Supply Chain Design Considering Customer Relationship Management," Resour. Conserv. Recycl., vol. 138, no. July, pp. 215-228, 2018, doi: 10.1016/j.resconrec.2018.07.018.

[9] N. Y. Jung and Y. K. Seock, "The impact of corporate reputation on brand attitude and purchase intention," Fash. Text., vol. 3, no. 1, 2016, doi: 10.1186/s40691-0160072-y. 